\title{
South Africa Meeting of the British Association.
}

\author{
Programmes of Sections.
}

Mathematics and Physics.

$\mathrm{A}^{\mathrm{T}}$ the forthcoming South Africa meeting, Section A (Mathematics and Physics) will be under the presidency of the Right Hon. Lord Rayleigh. Representatives from Great Britain of all branches of the Section will support him and will communicate papers in the two centres of the meeting, Cape Town and Johannesburg. Prof. Hevesy, who is a foreign guest, will open a joint discussion with the Section of Chemistry on quantitative chemical analysis by $\mathrm{X}$-rays and its applications, and a second joint meeting, in this case with the Section of Geography, will be held for a series of papers on geodesy and surveying. Recent work on atomic nuclei will be described by Sir Ernest Rutherford and Dr. Aston, and spectroscopic papers presented by Prof. MeLennan, Prof. A. Fowler, Mr. R. H. Fowler, and Mr. A. C. Menzies. Some aspects of the work of the National Physical Laboratory, to be dealt with by Dr. Ezer Griffiths, should bring to the notice of South Africans the important part played by the Laboratory in the scientific and industrial life of Great Britain. In Cape Town itself, some interesting communications are expected from Prof. Ogg and his colleagues in the University of Cape Town.

Cosmical physics, already strongly represented in South Africa itself, will receive the aid of Prof. de Sitter as a foreign guest, the Astronomer Royal, Prof. Eddington and Prof. Chapman. Lastly, the claims of mathematics will be met by papers from Sir Gilbert Walker, Mr. F. P. White, and Dr. Wrinch.

\section{Chemistry.}

THE address of Prof. G. Barger, as president of Section B (Chemistry), will be delivered at Cape Town, and is entitled "Applications of Organic Chemistry to Biology ". Organic and biochemical subjects occupy the major portion of the Cape Town programme. Prof. K. Freudenberg, of Heidelberg, will give a lecture on "The Vegetable Tannins", a subject of special interest in South Africa, and it is hoped to hear an account of "Essential Oils from South African Plants" by Prof. St. J. van der Riet, of Stellenbosch. Although the nature of vitamins from the chemical point of view was discussed so recently as the Leeds (1927) meeting, the rapid development of our knowledge of the vitamins since that time makes the joint discussion with Section I (Physiology) particularly opportune. On the one day at Cape Town devoted to general and inorganic chemistry, Dr. N. V. Sidgwick will give a lecture on "Chemical Linkage" and Prof. J. Smeath Thomas, of Cape Town, will give an account of "Recently discovered Nitrate Deposits in S.W. Africa". From Cape Town it is hoped that the Section will have the privilege of visiting the factory of The Cape Explosives Co. at Somerset West.

The sectional programme at Johannesburg is to be devoted almost entirely to inorganic and physical chemistry. Mr. H. A. White, of the Geduld Proprietary Gold Mines, Ltd., is to give an account of "The Chemistry of Gold Extraction", and two special features of the Johannesburg programme are a joint discussion with Section A (Physics) on "Qualitative Analysis by X-rays" to be opened by Prof. G. Hevesy, of Freiburg, and a lecture by Prof. E. C. Franklin, of Stamford University, California, on "The Ammonia System of Compounds". Mr. A. C. Egerton is to give an account of "The Influence of Antiknocks on the Combustion of Hydrocarbons ", and other important contributions to the programme are being made by Prof. H. Bassett and Dr. F. H. Constable.

\section{Geology.}

THE organisation of Section C (Geology) has been necessarily affected by the meeting of the International Geological Congress at Pretoria, and a programme has been adopted which, while enabling the section to carry on its work with the Association, yet allows its members to take some part in the proceedings of the Congress. Two sessions will be held at Cape Town and two at Johannesburg. Members of the Congress who wish to be present and take part in the proceedings at Johannesburg will be able to take advantage of the invitation which has been extended to them.

Sir Albert E. Kitson, of the Geological Survey of the Gold Coast, president of Section C, will deliver his address at Johannesburg on "The Utility of Geological Surveys to Colonies and Protectorates of the British Empire".

The special position that Africa takes in all questions involving continental drift makes the joint discussion with Sections D (Zoology) and K (Botany) specially appropriate. Phases of the problem may be touched in the papers by Prof. W. T. Gordon on "Some Limestone Erratics from the Beardsmore Glacier ", and Mr. W. N. Edwards on "Triassic-Rhætic Floras of the Southern Hemisphere". Dr. F. Dixey will describe the geology of the Lower Shire-Zambezi Basin, and Mr. F. P. Mennell will put forward "Some Suggestions as to the Origin of the Diamond Pipes ". Of wider interest is the paper of Prof. P. G. H. Boswell on "The Precipitating Action of Colloids on Fine-grained Sediments" : this opens a new field of investigation.

As is usual with Section C, the excursions are a feature of the programme. As these have been arranged by Dr. A. L. Hall, of the Union Geological Survey, and secretary of the International Geological Congress, their interest and importance is assured. Two half-day and one whole-day excursion will be made in the neighbourhood of Cape Town. The journey from Cape Town to Johannesburg will be spread over four days, with stops at Laingsburg and Kimberley. Between the two sessions at Johannesburg members will be able to join the Congress for the Witwatersrand excursion (three days).

\section{GeOgraphy.}

THE president of Section E (Geography) for the South Africa meeting is Brigadier E. M. Jack, Director-General of the Ordnance Survey, who will deal with "National Surveys" in his presidential address. Following this a series of papers will be read by Capt. McCaw, Dr. Van der Sterr, and others, dealing in further detail with cartographical and survey problems relating to Africa in general, and to South Africa in particular. In connexion with these, it may be recalled that at the Glasgow meeting the Section emphasised the importance of completing, as soon as possible, the survey of the arc of the thirtieth meridian, and urged also the need for the publication of a uniform series of maps of Africa on a scale of $1: 2,000,000$, as the only satisfactory base for various distributional studies in Africa. The significance of the latter will be further developed, along with other points, in a report to be presented by Mr. A. G. Ogilvie of a special committee which has been investigating problems connected with the geography of tropical Africa.

Various aspects of South African geography - both physical and human-will be analysed, both at Cape Town and Johannesburg, by local authorities, including Prof. J. H. Wellington and Prof. E. Walker. At Cape Town, Mr. Van Reenen, chairman of the

No. 3113, VoL. 123] 
Irrigation Commission, will review various problems connected with the utilisation of available water supplies in South Africa, while Prof. Serton will examine critically the extent to which the term 'desert' may be justifiably applied to various regions of low rainfall (for example, the Western Karroo, with an average annual rainfall of less than 5 inches in parts).

A meeting in a region of winter rains such as southwestern Cape Colony provides a fitting opportunity for a critical survey of "the Mediterranean Climatic Type, its World Distribution and the Human Re. sponse", which Dr. Marion Newbigin proposes to undertake. The various important problems connected with the South African sector of Antarctica will also be presented in a paper prepared by Mr. F. Debenham, and it is hoped that General Smuts will take part in the discussion on the matters raised.

The position of geography in South African education is not all that can be desired, and attention will be directed to this important aspect in a joint discussion that has been arranged with Section L at Johannesburg, a whole morning being devoted to the question.

Outside of Africa various interesting papers are being presented dealing with parts of both the southern and northern hemispheres. The significance of China's expansion in the Far East is to be considered by Prof. P. M. Roxby, while among the papers on Europe will be one by Prof. H. J. Fleure analysing the significance of various city types in the interpretation of the different cultural regions of the Continent.

Dr. Vaughan Cornish's interest in the æsthetics of scenery is now well known in Great Britain, and a paper by him on "The Rural Scenery of England and Wales" will be welcomed in South Africa.

\section{Economic ScIence and Statistics.}

THE programme for Section F (Economic Science and Statistics) of the British Association has now been arranged for the forthcoming meeting in South Africa, and, as was to be expected, special attention is to be devoted to those economic problems which are of importance in the Union. Labour questions, for example, are to be discussed in the light of South African conditions, and for this purpose a joint discussion has been arranged with the Anthropological Section on "Economic Competition between Advanced and Backward Peoples ", while Prof. A. Leslie is to speak on "Coloured Labour and Trade Unionism in Cape Town ". Another economic topic of considerable importance to South Africa is the marketing of agricultural produce and the joint meeting which has been arranged with the agriculturalists on "The Problem of Stabilising Agricultural Prices, with special reference to Control Boards, Equalisation Funds, and other methods of Price Regulation", should lead to an interesting discussion. It is anticipated that Mr. R. B. Forrester, Dr. Tinley, and Mr. R. J. Thompson will participate in this discussion. At Johannesburg, Dr. J. E. Holloway is to speak on "Population Problems of South Africa ", while Mr. W. H. Clegg will describe "South African Banking".

\section{EngINEering.}

Engineers attending the South Africa meeting of the British Association will have papers and discus. sions at both Cape Town and Johannesburg. The president of Section G (Engineering), Prof. F. C. Lea, will deliver his address at Johannesburg.

The principal subjects chosen for papers are of great importance to South Africa. At Cape Town Dr. Ezer Griffiths, of the National Physical Laboratory, and Mr. E. A. Griffiths, of Cape Town, will give papers on recent research work carried out in England and South
Africa in refrigeration. The successful export of fruit from the Union depends largely on this work.

The importance of transport, which is as great in South Africa as in any other country, will be dealt with from many different angles by English and South African authorities. Sir Henry Maybury will describe the developments which have taken place in Great Britain during the past few years, referring to the effect of recent legislation on road administration. Papers dealing with transport costs, alcohol fuels, railways, and roads as feeders to the railways will also be given. Sir Henry Fowler's paper will describe chiefly the work of the Directing Committee, of which he is a member, appointed by the British Government to study aspects of mechanical transport likely to further the economic development of the oversea Empire, and it is hoped that the discussions on these papers will be of great help to this committee.

At Johannesburg cheap power will be dealt with. Sir Charles Parsons will give a description of the more recent developments in steam turbine practice, chiefly in regard to the increased output per unit.

Prof. E. W. Marchant's paper on the limits of the economical transmission of electrical energy will have an added interest, for at the last South Africa meeting of the Association the late Prof. Ayrton made an important contribution on the transmission of power from the Victoria Falls. Mr. C. H. Merz will describe the development of the national scheme of electricity supply in Great Britain, and discuss the anticipated economies and the probable effects of the cheapening of electric power on the distribution of population and industries.

The acute problem in mining in South Africa is the cooling and ventilation of the deep mines, and the joint discussion of the Engineering and Physiological Sections on deep mine ventilation, to take place at Johannesburg, should prove very valuable.

\section{ANTHROPOLOGY.}

SouTH African anthropologists have prepared a full and interesting programme for Section $\mathbf{H}$ (Anthropology), in which archæology figures largely. There is ample evidence, however, that other branches of the science are not neglected in the Dominion, and it has been necessary to make arrangements for a subsection at Johannesburg to provide for a number of papers on physical anthropology by Prof. Dart and other members of the Anthropological School which centres in the University of the Witwatersrand. At Cape Town especial interest will attach to a series of papers on the Fish Hoek Caves, which will be followed by a visit to the caves themselves. The meeting at Cape Town will, however, be curtailed to allow the members of the Section to proceed in advance of the main body to Kimberley, where the collection of skulls and archæological exhibits in the Museum will be visited, Mr. Cronin's remarkable collection of photographs of South African natives will be viewed, and archæological excursions in the neighbourhood will be made.

The programme at Johannesburg will be particularly interesting. Prof. Dart will exhibit the Taungs skull, and arrangements have been made for a visit to the site of discovery. Mr. Leakey will describe his discoveries in the prehistory of East Africa, and Mr. Wayland will deal with the present position of Stone Age research in Uganda. Mr. C. von Riet Lowe will deal with the archæology of Sheppard Island, with an addendum on the associated fauna, and Prof. Dart will describe mammoths and other fossil elephants of the Transvaal, some of them not previously known.

The question of Bushman rock engravings will be discussed by Miss Wilman, a subject on which much illuminating discussion may be expected, in view of

No. 3113, VoL. 123] 
the visit of L'Abbé Breuil to South Africa as a guest of the Association and the demonstration of the Late Palæolithic art of Spain which he will give at Cape Town. Members of the party proceeding from England--Prof. Fleure, Prof. Ruggles Gates, Miss Murray, and others-will contribute to the proceedings.

The items in the sectional programme, however, which are expected to arouse the keenest interest are the papers centring around Zimbabwe. Dr. Leo Frobenius will give an account of the explorations of prehistoric Rhodesia made to date by the expedition of which he is leader. He will be followed by Miss Caton-Thompson, who will describe the results of the work, undertaken at the request of the Association, which she has carried out at Great Zimbabwe and on which she has been engaged since the beginning of the year on behalf of the Association.

\section{Physiology.}

SECTron I (Physiology) this year includes in its programme one or two unusual items. Probably the most striking is a joint discussion with the other biological sections on "The Nature of Life", which General J. S. Smuts has promised to open. Among the other speakers on this topic are Profs. D'Arcy Thompson, J. S. Haldane, Wildon Carr, and E. C. C. Baly. That an agreement will be reached is more than can be expected, but it is certain that much of interest will be said.

The Capetown part of the programme also includes joint meetings with Section D on experimental biology, one morning being mainly occupied by papers on this subject, and an afternoon being devoted to demonstrations on kindred topics in Prof. Lancelot Hogben's new laboratory. Many of the contributions, both here and at Johannesburg, are from South African workers, and the matters discussed range over a wide field.

At Johannesburg the most important feature probably is a joint discussion with Section G (Engineering) on "Problems connected with Deep-mine Ventilation ". The economic importance of this matter is very considerable, and it is hoped that members of the Transvaal Mining and Metallurgical Society will also be able to participate.

Of almost equal interest to physiologists and to economists is "The Problem of Dust Inhalation", on which also a discussion has been arranged. The sectional programme is now, however, restricted to questions connected with the mining industry. Papers are being contributed by local workers on the measurement and effects of ultra-violet light, and a varied programme includes a paper by Dr. Monckton Copeman on "Diet and Cancer", and a description of "The Feeding Habits of Vampyrella", with kinematograph accompaniment, by Prof. F. E. Lloyd, of McGill University.

\section{Psychology.}

SEction J (Psychology) meets this year under the presidency of Mr. F. C. Bartlett, the Director of the Cambridge Psyehological Laboratory, who in his address will discuss "Experimental Method in Psychology". The programme is full and varied; in it nearly every department of psychology is represented. A joint discussion has been arranged with Section L on "Psychological Tests in Relation to Education and Vocational Guidance", in which papers will be read by Prof. Reyburn, Dr. C. S. Myers, and Dr. Shepherd Dawson.

South African psychologists will present seven or eight papers, three of which, by Prof. Wilcocks, Prof. Eybers, and Dr. Fick, will report the results of investi- gations into the intelligence of South African children, both white and black. The philosophical aspects of psychology are represented by Prof. G. Dawes Hicks in a paper on "The Notion of Fusion in Psychology", by Prof. H. Wildon Carr, who will speak on "Imagination and Reasoning ", and by Prof. Forsyth of Bloemfontein, who will read a paper on the "Significance of Holism ", a philosophical theory propounded by General Smuts.

The Industrial Fatigue Research Board is represented by Mr. Eric Farmer, who will give an account of some of his own work on 'accident proneness'.

\section{Botany.}

Section K (Botany) has a very full programme both at Cape Town and at Johannesburg. The large number of papers to be communicated by South African workers indicates clearly the very active interest which is being taken there in botany at the present time. All branches of botany are well represented in the programme. Prof. Seward's presidential address on "Botanical Records of the Rocks" will be given at Johannesburg. As might be expected, much time will be devoted to papers on the South African flora, and there will be a discussion on its origin and evolution, in which Dr. Marloth, Prof. Bews, Prof. Compton, Dr. Pole Evans, Prof. Adamson, Prof. Moss, and others will take part. Dr. Pole Evans will also give an account of the present position of the botanical survey of South Africa. Prof. F. E. Lloyd will exhibit a film illustrating the mechanism of the trap of Utricularia, and Dr. A. S. Hitcheock, of the Smithsonian Institution, will speak on the subject of grasses in relation to man. Miss Saunders will discuss her recent work on carpel morphology.

Popular lectures will be given by Dr. Margery Knight on "Seaweeds, a Study of Adaptation and Opportunity", and by Prof. Priestley on "From Lake to Veld: a Study of the Water Relations of the Higher Plant". The forestry group also has an interesting programme, in which contributions from persons interested in forestry problems in South Africa are prominent. Numerous excursions to places of botanical interest have been arranged.

\section{Education.}

THE programme of Section L (Educational Science) is promising and varied. Two objects have been kept in mind in its preparation: $(a)$ the desirability of showing the recent development in educational administration, practice, and teaching in England; and (b) the presentation and discussion of South African problems.

Dr. Kimmins has chosen for his presidential address the subject "Modern Movements in Education". One session at Cape Town is to be devoted to general educational problems in South Africa, when five separate papers will be given by leading experts.

At Johannesburg a full session will be devoted to " Education and the Native Races ", four papers being expected. At a joint session with Section $J$ at Cape Town, leading psychologists from both countries will discuss psychological tests in relation to education and vocational guidance. Other sessions at Cape Town will be given to discussions on the relation of examinations to the secondary schools and on the teaching of science, including biology and botany, in schools. At Johannesburg, at a joint session with Section E, papers will be given on the teaching of geography by members from both countries.

Committees of the Section will also present reports on science in the school certificate, formal training and training for life overseas.

No. 3113, Vou. 123] 


\section{Agriculture.}

Perhaps the most significant development which has taken place in agricultural science is the realisation of the very close relationship between soil and animal nutrition problems as they exist in Great Britain and the various Dominions of the Empire.

The fact that much of the work in progress in the British Isles has a direct bearing on Dominion problems has resulted in a desire for closer touch and collaboration between research workers in various parts of the Empire. This trend was emphasised and focused at the Imperial Agricultural Conference in London in 1927 and practical recognition has been given by the creation in the British Isles of Agricultural Bureaux in Soil Science, Animal Nutrition, Plant Breeding, Animal Genetics, and Veterinary Science. It is fitting, therefore, that by far the greater part of the programme for Section M (Agriculture), which is meeting at Cape Town and Pretoria, should be occupied by the discussion of broad agricultural problems. Two whole sessions are being devoted to soil problems, the first at Cape Town to a discussion on soil fertility and its control, and the second at Pretoria to methods of soil investigations in field and laboratory.
A morning session will be occupied by a discussion on Empire wool growing problems with particular reference to South Africa and to the manufacturing requirements of Great Britain. Grassland and the production of stock is another problem of world-wide range, the fundamental aspects of which are similar in all parts of the Empire. Major Walter Elliot will open a discussion on the mineral aspects of pasture nutrition in relation to the live stock industry, and representatives of the Rowett Research Institute, Aberdeen, and the South African Veterinary Research Station will contribute.

The possibility of stabilising agricultural prices and the methods of achieving the object in view continue to exercise the minds of farmers and economists the world over, and considerable experience has been acquired in South Africa, Canada, and New Zealand. Section M has arranged for a joint discussion with Section F (Economics) on this subject, with particular reference to the operation of control boards, equalisation funds and other methods of price regulation. Agriculture and the Empire will form the subject of Sir Robert Greig's presidential address to Section M, and the address, together with a discussion on Empire agricultural problems, will occupy the whole of the second morning session at Pretoria.

\section{Some Function Problems attaching to Convergence. ${ }^{1}$}

THE arrangement of the conducting paths of the nervous system, branching and redistributing their impulses as they do, exhibits places where numerous convergent paths run into one. When at such places two or more of the converging arcs are concurrently active, the trains of impulses arriving by them can interact. Such convergent places are co-ordination points. An example of much importance, and relatively accessible to experiment, is that in the spinal cord, where the motor nerve-cells innervating a muscle receive as a group the various afferent paths which reflexly operate the muscle. If two or more of the convergent afferent nerves are excited concurrently, the reflex interaction, as revealed by the muscle, exhibits three main sets of cases.

In one set of cases the muscular response under concurrent stimulation of two or more afferents shows a deficit in amount as compared with the sum of the responses obtainable from the several afferents taken separately. This occurs especially when the excitation of the reflexes is strong; it is most marked when they are of maximal strength. The contraction effect of one afferent may default altogether. The result might seem to indicate inhibition, but analysis shows that it is not referable to any form of inhibition.

The explanation lies in the limitations of the mechanical response of the muscle fibres of the motorunits activated : the contraction effect pertaining to one afferent being 'occluded' for the time being by that pertaining to another. 'Occlusion' is a result of the overlap of different afferent arcs upon the same motor-units : this overlap is 'central', for example, in the spinal cord. The amount of 'occlusion' as observed by the myograph gives a measure of the amount of that ' central 'overlap. In such estimates, however, the assumption is made that the component motor-units of the muscle all of them possess individually the average value of contraction-tension which obtains for them. This in the knee-flexor (cat) semitendinosus has a value which is only one-third of that obtaining for gastrocnemius. It is, however, certain that the individual motor-units differ con-

${ }^{1}$ Summary of the David Ferrier Lecture delivered before the Royal Society on Thursday, June 20, by Sir Charles Sherrington, O.M., F.R.S. siderably in contraction-value within one and the same muscle. Examined by occlusion, the overlap of the constituent branches of a single large afferent nerve upon its motor-units can be well above tenfold. This gives a functional picture in harmony with the histological picture furnished long since by Cajal.

In another set of cases, on the contrary, the contraction response of the muscle, under concurrent stimulation of two or more reflex ares which are excitatory for it, shows a surplus of contraction as compared with the sum of the responses to the component afferents taken separately. This result is most evident with weak reflexes. As with the other set of cases this result also, although opposite to the previous class, brings evidence of the overlap of the convergent arcs upon the central ends of motor-units held by them in common. Moreover, evidence is thus furnished that central states of excitement, individually too weak to provoke the motor-units into discharging activity, can by summation become effective for that activation.

The reflex excitation provoking contraction of the muscle is shown to be accompanied regularly in the spinal centre by concomitant subliminal excitation in other spinal motor cells over and above those excited to actual discharge. The time relation of central subliminal excited states obtaining in certain typical reflexes has been determined (J. C. Eccles). By the summation of subliminal excited states this fringe of subliminal effect is a functional means of liaison enabling co-operation between different adjuvant parts of the nervous system. Although the neuron upon which convergent ares interact is subject to their combined influence, and is to that extent an instrument passive in their hands, it is an instrument clearly with ways of its own. Thus, to receipt of a single stimulus it may react by a response consisting of a whole tetanic series of impulses.

Another and third set of cases arising from interaction at the convergence point is where the upshot is inhibition. The clash is between 'central ' excitation and a central process which arrests or precludes it, but about which all that is known is that it antagonises excitation. Evidence was adduced of the

No. 3113, VoL. 123] 